\title{
Evidence for the hybrid origin of Nymphoides montana Aston (Menyanthaceae)
}

\author{
Nicholas P. Tippery ${ }^{1}$ and Donald H. Les \\ Department of Ecology and Evolutionary Biology, University of Connecticut, Storrs, \\ Connecticut 06269-3043 USA \\ ${ }^{1}$ Author for correspondence: nicholas.tippery@uconn.edu
}

\begin{abstract}
Nymphoides is a genus of approximately 50 species worldwide, and arguably achieves its greatest diversity in tropical northern Australia, where most of the 20 native species occur. Species found at temperate latitudes are restricted to the eastern half of the country; of these, three ( $N$. crenata, $N$. geminata, N. indica) also occur in the tropics, and two (N. montana and N. spinulosperma) are only temperate. During an ongoing phylogenetic study of the genus, DNA sequences from $N$. montana were a major source of incongruence between phylogenetic trees derived from nuclear (nrITS) and chloroplast $(r b c \mathrm{~L}, \operatorname{trnK})$ data matrices. Our phylogenetic analysis revealed that N. montana resolved variously with $N$. geminata (nuclear data) and N. spinulosperma (chloroplast data), which despite their strong morphological similarity, are not closely related to each other. These results indicate a hybrid origin for N. montana, which subsequently retains evidence of its maternal lineage in the chloroplast genome, whereas nuclear DNA markers (nrITS data) have been converted to resemble the paternal lineage exclusively.
\end{abstract}

\section{Introduction}

Nymphoides Ség. (Menyanthaceae) includes approximately 50 species worldwide and generally is characterised by a submersed rhizome and floating leaves that support clusters or lax racemes of pentamerous flowers (Tippery et al. 2008). Most of the 20 Australian species are exclusively tropical, but several are found in the southeast (Jacobs 1992; Aston 2003, 2009). Two species (N. montana Aston and N. spinulosperma Aston) occur only at temperate latitudes; both were described recently by Aston $(1982,1997)$ as part of her thorough study of Australian Nymphoides. Morphologically, these species are quite similar to each other and also to N. geminata (R.Br.) Kuntze, a rather widespread species and one of the first Menyanthaceae to be catalogued from the continent (Brown 1810). Nymphoides geminata, N. montana, and N. spinulosperma share the yellow flowers and expanded inflorescence habit that characterise the informal 'geminata group' to which they were assigned by Aston $(1982,1997)$. However, the three species differ from each other by their seed morphology, which Aston (2003) considered to 
be highly diagnostic. The seeds of $N$. geminata are globose and sparsely tuberculate, those of N. montana are smooth and compressed laterally, and N. spinulosperma seeds are compressed and distinctly covered with tapering tubercles (Aston 2003). These species also differ markedly from their two sympatric congeners: N. indica (L.) Kuntze has white flowers that are covered in ciliate hairs and borne in umbellate clusters, and N. crenata (F.Muell.) Kuntze has petals with median wings and is the only Nymphoides species with a pentamerous gynoecium (Aston 1973, Jacobs 1992).

Prior molecular phylogenetic work on Menyanthaceae has included every species in all genera other than Nymphoides (Tippery et al. 2008, 2009), but relationships of relatively few taxa within this genus have been addressed to date. These previous studies established that the anomalous species N. exigua (F.Muell.) Kuntze did not belong in Nymphoides but rather to Liparophyllum Hook.f., to which it was transferred under an expanded genus concept that also included several former species of Villarsia Vent. (Tippery et al. 2008, Tippery \& Les 2009). All other Nymphoides species analysed to date resolve as a strongly monophyletic group, within which the 'indica group' (i.e., species with a densely clustered inflorescence supported by a single floating leaf; Aston 1982) form a clade subtended by the paraphyletic 'geminata group' (Tippery et al. 2009).

Australian Nymphoides species span both groups of inflorescence architecture, and also vary in their sexual condition. Dimorphic heterostyly, the reciprocal separation of anthers and stigma on different plants, often accompanied by ancillary morphological differences and self-incompatibility between plants of the same morph type (Haddadchi 2008), is widespread in Menyanthaceae. A few species (including several Nymphoides) are homostylous, having flowers that lack the spatial separation of floral organs as well as the accompanying self- and intramorph incompatibility (Aston 1973, Jacobs 1992, Haddadchi 2008). The heterostylous condition promotes outcrossing, which is an important mechanism in Nymphoides where highly clonal populations often are established by vegetative propagation (e.g., through stolons or fragmentation; Haddadchi 2008). One fundamental difference between $N$. geminata and N. montana is that the former is homostylous and the latter heterostylous (Ornduff 1970, Jacobs 1992, Haddadchi 2008). The different sexual conditions of N. geminata and N. montana also correlate ecologically. Nymphoides geminata successfully self-pollinates, even autonomously (i.e., without pollinator activity), and can tolerate marginal habitats (e.g., extensive water level fluctuation), whereas N. montana is self- and intramorphincompatible and tends to inhabit more stable water bodies (Haddadchi 2008). Less information is available for the more narrowly distributed N. spinulosperma, although Aston (1997) did refer to the species as heterostylous.

During an ongoing phylogenetic study of Nymphoides, we noted that DNA sequences of $N$. montana resolved to different positions on trees that were derived using either nuclear or chloroplast data. By investigating a broad sample of species, we observed that the nuclear data placed $N$. montana as a close sister species to $N$. geminata while the chloroplast data resolved it with N. spinulosperma. Prior results indicated that the latter two taxa are not closely related to each other (Tippery et al. 2009). Herein we present the results of a phylogenetic study directed at resolving the closest-related species to N. montana and its morphological affinities to these putative relatives, and discuss the evidence indicating the hybrid origin of this taxon. 


\section{Materials and Methods}

Nymphoides specimens for DNA analysis were collected and preserved in CTAB (Rogstad 1992), or obtained from dried herbarium material. Specimens of N. geminata, N. montana, and N. spinulosperma were identified using published descriptions (Aston 1982, 1997, 2003), cognisant of potential taxonomic confusion regarding the identity of N. geminata as reported in some of the earlier literature (e.g., Aston 1973). DNA sequences from multiple accessions of the same taxon were compared initially. After finding minimal sequence variation within a taxon $(<0.3 \%$ divergence in pairwise comparisons), phylogenetic trees were simplified by using only one accession of each taxon for phylogenetic analyses (Appendix 1). The outgroup comprised seven species of Liparophyllum (sensu Tippery \& Les 2009), which molecular analyses have resolved as the sister clade of Nymphoides (Tippery et al. 2008, 2009). Locality data were collected from literature sources (Aston 1982, 1997; Haddadchi 2008) and from herbarium specimens that were verified during this study (Appendix 1).

DNA extraction, amplification, and sequencing of the nuclear ribosomal internal transcribed spacer (nrITS) and the chloroplast $r b c \mathrm{~L}$ gene and $\operatorname{trn\mathrm {K}} 5$ ' intron, plus proofreading and alignment of sequence chromatograms, followed Les et al. (2008) using primers specified by Tippery et al. (2008). Gaps in the alignment, representing insertions or deletions (indels), were coded using simple indel coding (Simmons \& Ochoterena 2000) in the program SeqState (Müller 2005, 2006). Molecular sequence data generated for this study were deposited in GenBank (accession numbers HQ184901-HQ184921; Appendix 1), and aligned data and indel matrices were submitted to TreeBASE (study number S10810; http://treebase.org/).

Data were analysed separately (nrITS, $r b c \mathrm{~L}, \operatorname{trn\mathrm {K}}$ ) and in combination, under both equally weighted maximum parsimony and maximum likelihood methods. Prior to combining data, partition-homogeneity / incongruence length difference (ILD) tests were conducted using PAUP ${ }^{\star}$ ver. $4.0 \mathrm{~b} 10$ (heuristic search, 1,000 replicates, maxtrees=1,000; Farris et al. 1994, Swofford 2002) in order to evaluate the relative congruency of the different data partitions examined, using a significance threshold of $p<0.01$. After finding significant incongruence between nuclear (nrITS) and chloroplast ( $r b c \mathrm{~L}$ and $t r n \mathrm{~K})$ data (see Results), we identified the major source of incongruence (N. montana) using species jackknifing (Lecointre \& Deleporte 2005). Subsequently, we artificially separated the data for N. montana into two 'taxa', one each representing the nuclear and chloroplast data.

Heuristic tree searches were performed under parsimony in PAUP* (Swofford 2002) with 100 replicates of random stepwise addition (maxtrees $=100,000)$ and branch swapping by tree bisection and reconnection (TBR). Support for internal nodes was evaluated using 1,000 bootstrap replicates in PAUP* with the following options: heuristic search, one random stepwise addition per replicate, swapping by TBR, and maxtrees $=10,000$. After model selection with jModeltest ver. 0.1.1 under the AIC criterion (Posada 2008), likelihood analysis was implemented using GARLI ver. 0.96. r396 (Zwickl 2006), with the combined data matrix partitioned among nrITS DNA (TIM3 ef $+\mathrm{G}$ ), nrITS indels (Mkv model; Lewis 2001), rbcL DNA (TIM2+I), trnK DNA $(\mathrm{TVM}+\mathrm{G})$, and $\operatorname{trn\mathrm {K}}$ indels $(\mathrm{Mkv})$. Ten separate likelihood runs were performed using different random starting seeds, and the tree with the maximum likelihood score was compared with the parsimony consensus tree. Bootstrap analysis (1,000 replicates) was conducted using GARLI. 


\section{Results}

We obtained nucleotide sequences for 35 accessions of 20 taxa, including seven outgroup and ten ingroup taxa that were studied previously by Tippery et al. (2008, 2009), three accessions of N. geminata, nine of N. montana, and six of N. spinulosperma (Appendix 1). Multiple accessions of the latter three taxa largely spanned their respective species' ranges except for $N$. montana, for which collections were clustered roughly at the centre of its range (Fig. 1).

Aligned nucleotide and indel data were obtained for nrITS DNA (874 nucleotide characters, 146 parsimony-informative, $1.2 \%$ missing data), nrITS indels ( 98 characters, 48 parsimony-informative), $r b c \mathrm{~L}$ DNA (1348 characters, 32 parsimony-informative, 4.1\% missing), trnK DNA (1074 characters, 35 parsimony-informative, $1.4 \%$ missing), and $\operatorname{trnK}$ indels ( 14 characters, 4 parsimony-informative), for a total of 3,408 characters. Partition-homogeneity analysis showed that the $r b c \mathrm{~L}$ and $t r n \mathrm{~K}$ data (including indels) were congruent $(p=0.73)$, but the partition of chloroplast $(r b c \mathrm{~L}$ and $\operatorname{trnK}$, including indels) versus nuclear (nrITS DNA and indels) data showed significant incongruence $(p=0.001)$. Successive pruning of taxa rendered the $p$-value non-significant $(p=0.32)$ by removing only $N$. montana.

Phylogenetic analyses of combined data resulted in six most-parsimonious trees (748 steps, consistency index $=0.81$, retention index $=0.87$ ) and a maximum-likelihood value (natural logarithm) of $-8,588$ (Fig. 2). Nymphoides was strongly supported as

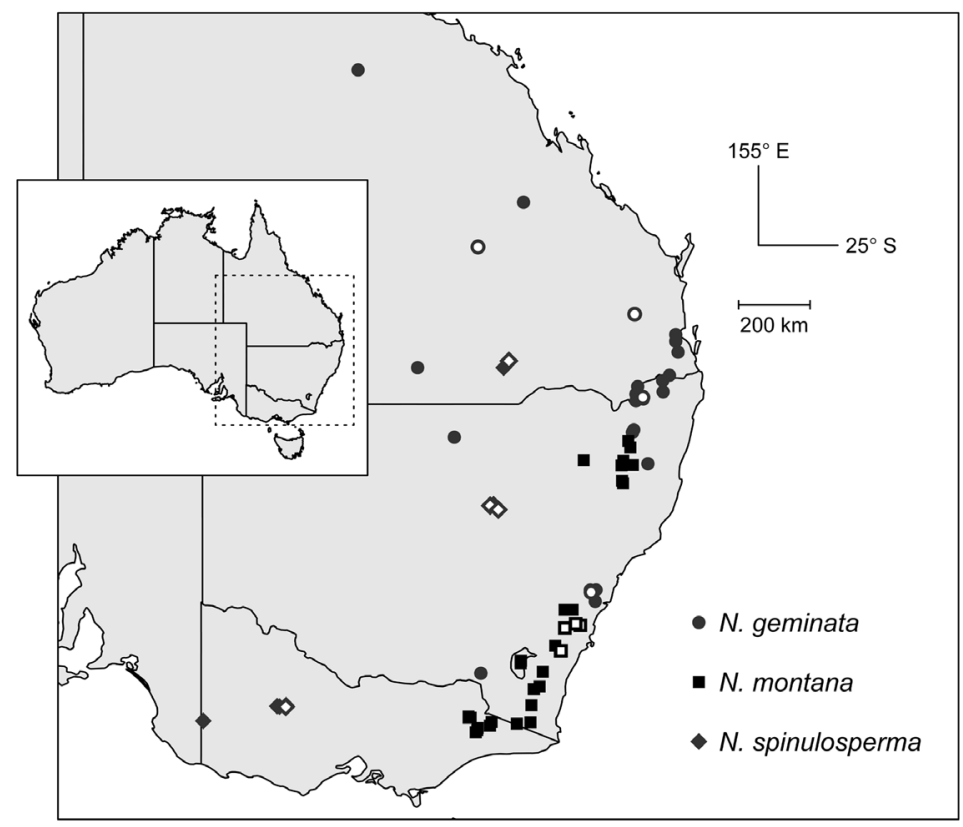

Fig. 1. Localities of specimens examined for this study. Owing to superficial morphological similarity and potential taxonomic confusion regarding the taxa involved, only specimens that were reported in recent literature (Aston 1982, 1997; Haddadchi 2008) or verified by the authors (Appendix 1) are included. Open shapes identify collection localities of specimens from which molecular data were obtained. 


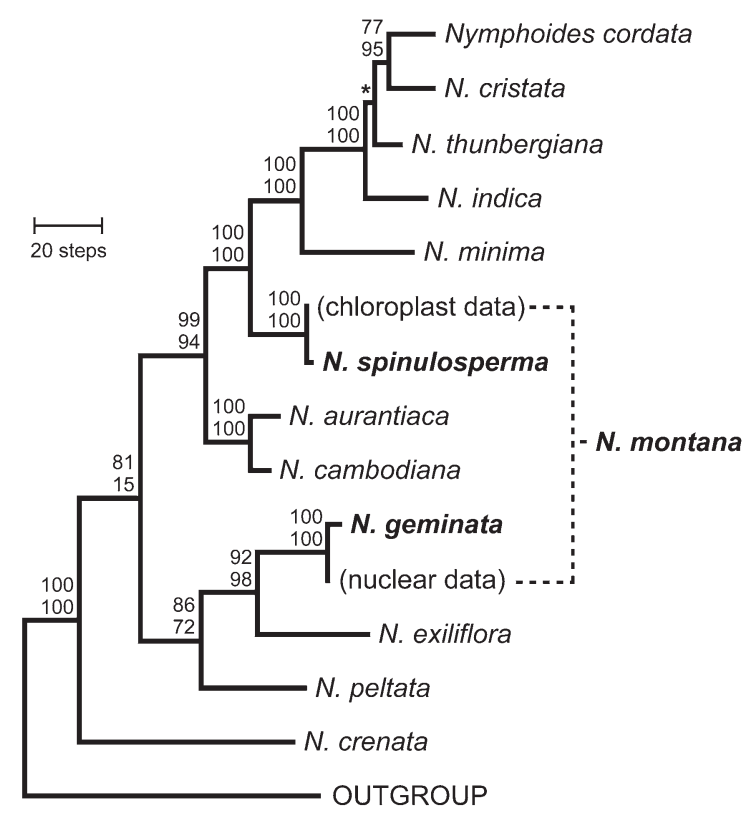

Fig. 2. One of six most-parsimonious trees constructed using combined nuclear (nrITS) and chloroplast $(r b c \mathrm{~L}, \operatorname{trn} \mathrm{K})$ molecular sequence data evaluated under the parsimony criterion. Branch lengths are proportional to the number of changes inferred, with scale given. Outgroup taxa of Liparophyllum (sensu Tippery \& Les 2009) were condensed for clarity. The single ingroup branch that collapses in the strict consensus tree is indicated by an asterisk $\left.{ }^{*}\right)$. Other branches are labelled with their bootstrap support values, with parsimony above and likelihood below. Nymphoides montana was split into two artificial taxa, one each for its nuclear and chloroplast data, which are connected by a dashed line. Taxa discussed in the text are indicated in bold.

monophyletic relative to the outgroup, and all internal relationships were well supported except for the placement of $N$. crenata, which resolved variously as sister to the rest of Nymphoides (parsimony) or sister to the clade containing N. peltata (likelihood); the competing alternate topologies, however, were supported only moderately (Fig. 2).

The nuclear data resolved $N$. montana in a clade with $N$. geminata, from which its nrITS sequence differed by four characters; chloroplast data resolved N. montana with $N$. spinulosperma, with only one character differing between them (Fig. 2). Multiple accessions did not differ by any parsimony-informative characters within a taxon, except for one N. spinulosperma accession (Aston 2880; Appendix 1), which matched the $\operatorname{trn} \mathrm{K}$ sequences for $N$. montana exactly. We also have sampled all other Nymphoides taxa in Australia (N.P.T., unpublished data), and have found no other sequences to be more similar to N. montana than those presented here as putative parental lineages.

\section{Discussion}

Nymphoides are morphologically diverse in Australia, where species are found with both condensed and expanded inflorescences and a great variety of floral and seed morphologies. Surprisingly, phylogenetic analysis indicated that N. geminata and 
N. spinulosperma, two of the most morphologically similar and geographically proximate species, were not closely related (Tippery et al. 2009, fig. 2). Moreover, $N$. montana, a species that also resembles these taxa, appears to be of hybrid origin, with a paternal lineage more closely related to N. geminata (to which its nuclear DNA is most similar) and a maternal lineage related to $N$. spinulosperma (indicated by the affinity of its chloroplast DNA).

The interrelationships of the taxa involved are supported by their geographic proximity. All three species grow primarily in the temperate east of Australia (Fig. 1), where only two other Nymphoides occur (see Introduction). Nymphoides geminata, N. montana, and the less well-known N. spinulosperma are worthy of comparison in light of the relationships presented here. Nymphoides geminata and N. spinulosperma are relatively widespread, although the latter exists in only a few localised areas, and N. montana is rather densely distributed near the coast (Fig. 1). Nymphoides geminata and N. montana differ by their flower size, pollinator visitation, self-compatibility, and pollen:ovule ratios, all of which potentially are correlated with the ecological niche of each species (Haddadchi 2008).

Both N. montana and N. spinulosperma are heterostylous, whereas N. geminata is one of few homostylous Nymphoides in Australia (Aston 1973, 1982, 1997; Haddadchi 2008). In a study comparing the sexual systems of N. geminata and N. montana, Haddadchi (2008) found evidence of functional heterostyly in the latter, with ancillary morphological traits (e.g., pollen and stigma dimorphism), populations with equal morph ratios, and self- and intramorph incompatibility; on the other hand, N. geminata was homostylous and highly self-fertile. The ploidy level of both $N$. geminata and $N$. montana was determined to be $2 \mathrm{n}=54$, although one population of the latter had 2n = 36 (Haddadchi 2008). In another study, Ornduff (1970) obtained the count of $2 \mathrm{n}=36$ for both taxa, which at that time were considered to be a single species. Similar intraspecific chromosome number variation also has been observed in Ornduffia parnassifolia (Labill.) Tippery \& Les (= Villarsia parnassifolia (Labill.) R.Br.; Ornduff \& Chuang 1988).

Morphologically, N. montana possesses parental characters of both N. geminata and N. spinulosperma as well as some novel features (cf. Rieseberg \& Ellstrand 1993). The pink pigmentation at the leaf and petiole junction characteristic of N. spinulosperma (Aston 1997) was observed in some specimens of N. montana (e.g., Aston 1820, Bell 108, Kodela 208, all at NSW; Betche s.n. Dec 1898, Briggs s.n. 27 Dec 1965, Briggs s.n. 28 Dec 1965, all at UC; Appendix 1) but is consistently absent in N. geminata. Pink or purple leaf coloration is generally uncommon in Nymphoides, but it has been observed also on the leaves of the related species $N$. aurantiaca (Dalzell) Kuntze (N.P.T., personal observation). The seeds of N. montana resemble N. geminata by their polygonal junction of epidermal cells (they are interdigitate in N. spinulosperma), but are more like N. spinulosperma by their compressed, elliptical shape (globose in N. geminata) and also by their length (1.1-1.6 mm vs. $0.5-1.2 \mathrm{~mm}$ in N. geminata; Aston 2003). Nymphoides montana is unique among the three species in having smooth seeds, whereas N. geminata and N. spinulosperma have tuberculate cell extensions (although smooth seeds occur occasionally in the former; Aston 2003). Seed morphology varies widely among Nymphoides species, and although the seed character combinations above are diagnostic for the species mentioned, their individual traits (e.g., seed shape or the presence of tubercles) are not unique (Aston 2003). 
Hybridisation occurs commonly in plants and has become increasingly easier to discern using DNA sequencing and cloning methods (Rieseberg 1997, Soltis \& Soltis 2009). Evidence of relatively recent hybridisation is apparent in the often-sequenced nrITS region, which exists as tandem repeats that tend (in non-hybrid lineages) to be uniform across all copies, owing to the process of concerted evolution (Álvarez \& Wendel 2003). However, in many recently derived hybrids, where concerted evolution has not had sufficient time to assimilate all copies of nrITS, the differences appear as sequence polymorphisms that then can be separated by molecular cloning (e.g., Moody \& Les 2002). In some situations the ongoing process of concerted evolution is evidenced by the existence of chimeric sequences, i.e., nrITS sequences that exist as various recombinant copies of the two parental sequences (e.g., Les et al. 2009), or by copies that are intermediate between the parental sequences, i.e., the result of crossingover followed by gene conversion (Álvarez \& Wendel 2003).

We interpret the situation encountered in N. montana to represent the uniform conversion of nrITS to the paternal lineage, perhaps through continued introgression of pollen from a common ancestor of $N$. geminata, together with a static chloroplast background derived from the maternal N. spinulosperma lineage. Further sequencing of other nuclear and chloroplast loci is planned in the hope of providing additional data to support this hypothesis. Moreover, both the chloroplast and nuclear DNA of $N$. montana have diverged from the parental lineages, indicating that substantial time has elapsed since the hybridisation event. Evidence exists in other hybrid-origin groups to suggest that discordant copies of nrITS can convert entirely to represent one or the other parent, although the mechanism of conversion and the likelihood of converting to one copy or the other are not known (Álvarez \& Wendel 2003, Volkov et al. 2007, Calonje et al. 2009).

At odds with our interpretation are the significantly lower pollen abundance and paucity of pollinator activity observed in the homostylous N. geminata (Haddadchi 2008), because these factors would facilitate inbreeding and decrease its likelihood of serving as the pollen parent of a hybrid cross. However, homostyly may not represent the ancestral condition of N. geminata; heterostyly is widespread in Nymphoides and most likely represents the ancestral condition for the entire genus (Tippery et al. 2008). It is possible that the original cross that produced $N$. montana occurred between two heterostylous species, with one eventually evolving into the present-day homostylous $N$. geminata. Subsequent to its hybrid origin, ecological differentiation between $N$. montana and its pollen parent may actually have been a factor in the evolution of homostyly in N. geminata. Further research should be directed to seek additional evidence in support of the hybrid origin of $N$. montana and also to corroborate the identity of its parental lineages and elucidate their reproductive ecology.

\section{Acknowledgments}

We are extraordinarily indebted to Surrey Jacobs for sharing his expertise on Australian Nymphoides and for collecting specimens for this study. We also thank the staff and directors of several herbaria (BRI, K, NSW, UC) for granting access to specimens, Helen Aston and Azadeh Haddadchi for helpful discussion, two anonymous reviewers for comments on our manuscript, and the editorial staff of Telopea for organising and inviting us to participate in this special issue. 


\section{References}

Álvarez I \& Wendel JF (2003) Ribosomal ITS sequences and plant phylogenetic inference. Molecular Phylogenetics and Evolution 29: 417-434.

Aston HI (1973) Aquatic Plants of Australia. (Melbourne University Press: Carlton, Victoria)

Aston HI (1982) New Australian species of Nymphoides Séguier (Menyanthaceae). Muelleria 5: $35-51$.

Aston HI (1997) Nymphoides spinulosperma (Menyanthaceae): a new species from south-eastern Australia. Muelleria 10: 21-25.

Aston HI (2003) Seed morphology of Australian species of Nymphoides (Menyanthaceae). Muelleria 18: 33-65.

Aston HI (2009) Notes on Australian taxa of Nymphoides (Menyanthaceae): typification and nomenclature. Muelleria 27: 119-126.

Brown R (1810) Prodromus Florae Novae Hollandiae et Insulae van-Diemen (London: Typis R. Taylor et Socii)

Calonje M, Martín-Bravo S, Dobeš C, Gong W, Jordon-Thaden I, Kiefer C, Kiefer M, Paule J, Schmickl R \& Koch MA (2009) Non-coding nuclear DNA markers in phylogenetic reconstruction. Plant Systematics and Evolution 282: 257-280.

Farris JS, Källersjö M, Kluge AG \& Bult C (1994) Constructing a significance test for incongruence. Systematic Biology 44: 570-572.

Haddadchi A (2008) Floral variation and breeding system in distylous and homostylous species of clonal aquatic Nymphoides (Menyanthaceae). Ph.D. Thesis. (University of New England: Armidale)

Jacobs SWL (1992) Menyanthaceae. Pp. 506-508 in Harden GJ (ed.) Flora of New South Wales, vol. 3. (New South Wales University Press: Kensington)

Lecointre G \& Deleporte P (2005) Total evidence requires exclusion of phylogenetically misleading data. Zoologica Scripta 34: 101-117.

Les DH, Jacobs SWL, Tippery NP, Chen L, Moody ML \& Wilstermann-Hildebrand M (2008) Systematics of Vallisneria (Hydrocharitaceae). Systematic Botany 33: 49 -65.

Les DH, Murray NM \& Tippery NP (2009) Systematics of two imperiled pondweeds (Potamogeton vaseyi, P. gemmiparus) and taxonomic ramifications for subsection Pusilli (Potamogetonaceae). Systematic Botany 34: 643-651.

Lewis PO (2001) A likelihood approach to estimating phylogeny from discrete morphological character data. Systematic Biology 50: 913-925.

Moody ML \& Les DH (2002) Evidence of hybridity in invasive watermilfoil (Myriophyllum) populations. Proceedings of the National Academy of Sciences USA 99: 14867-14871.

Müller K (2005) SeqState - primer design and sequence statistics for phylogenetic DNA data sets. Applied Bioinformatics 4: 65-69.

Müller K (2006) Incorporating information from length-mutational events into phylogenetic analysis. Molecular Phylogenetics and Evolution 38: 667-676.

Ornduff R (1970) Cytogeography of Nymphoides (Menyanthaceae). Taxon 19: 715-719.

Ornduff R \& Chuang TI (1988) Chromosome numbers of Western Australian species of Villarsia (Menyanthaceae). Plant Systematics and Evolution 161: 49-52.

Posada D (2008) jModelTest: Phylogenetic model averaging. Molecular Biology and Evolution 25: $1253-1256$.

Rieseberg LH (1997) Hybrid origins of plant species. Annual Review of Ecology and Systematics 28: 359-389.

Rieseberg LH \& Ellstrand NC (1993) What can molecular and morphological markers tell us about plant hybridization? Critical Reviews in Plant Sciences 12: 213-241.

Rogstad SH (1992) Saturated NaCl-CTAB solution as a means of field preservation of leaves for DNA analyses. Taxon 41: 405-458.

Simmons MP \& Ochoterena H (2000) Gaps as characters in sequence-based phylogenetic analyses. Systematic Biology 49: 369-381. 
Soltis PS \& Soltis DE (2009) The role of hybridization in plant speciation. Annual Review of Plant Biology 60: 561-588.

Swofford DL (2002) PAUP*: Phylogenetic analysis using parsimony (*and other methods), ver. 4. (Sinauer Associates: Sunderland, Massachusetts)

Tippery NP \& Les DH (2009) A new genus and new combinations in Australian Villarsia (Menyanthaceae). Novon 19: 406-413.

Tippery NP, Les DH, Padgett DJ \& Jacobs SWL (2008) Generic circumscription in Menyanthaceae: a phylogenetic evaluation. Systematic Botany 33: 598-612.

Tippery NP, Les DH, Regalado Jr. JC, Averyanov LV, Vu Ngoc Long \& Raven PH (2009) Transfer of Villarsia cambodiana to Nymphoides (Menyanthaceae). Systematic Botany 34: 818-823.

Volkov RA, Komarova NY \& Hemleben V (2007) Ribosomal DNA in plant hybrids: inheritance, rearrangement, expression. Systematics and Biodiversity 5: 261-276.

Zwickl DJ (2006) Genetic algorithm approaches for the phylogenetic analysis of large biological sequence datasets under the maximum likelihood criterion. Ph.D. Dissertation. (University of Texas: Austin)

Manuscript received 27 February 2010, accepted 27 September 2010

\section{Appendix 1.}

Verified specimens of Nymphoides geminata, N. montana, and N. spinulosperma evaluated in this study, followed by ingroup and outgroup taxa that were sequenced previously (Tippery et al. 2008, 2009). GenBank accession numbers are indicated in parentheses for nrITS, $r b c L$, and $\operatorname{trnK}$, respectively; asterisks $\left(^{*}\right)$ indicate which sequences were used for phylogenetic analyses, and dashes (-) indicate genes not sequenced. Collection localities for specimens listed here and those reported by Aston (1982, 1997) and Haddadchi (2008) are depicted in Fig. 1.

Nymphoides geminata (R.Br.) Kuntze - New South Wales. Carroll's Creek, Tenterfield, Constable s.n. 02 Dec 1965 (UC; EF173037, EF173103, EF173073); Narran Lake Nature Reserve, $50 \mathrm{~km} \mathrm{~W}$ of Walgett, Bell 151 (NSW); Windsor - Blacktown road, Blaxell s.n. 25 May 1960 (NSW); ibid. Blaxell s.n. 20 Oct 1960 (NSW); ibid. Blaxell s.n. 22 Sep 1961 (NSW); Boonoo Boonoo, Boorman s.n. Feb 1905 (NSW); 2 miles by road south of Woodenbong, Constable 6622 (NSW); Sandy Creek, c. 3 miles south of Old Benalbo, Constable s.n. 26 Oct 1961 (NSW); Carroll's Creek, 17.5 miles by road N. of Tenterfield, Constable s.n. 02 Dec 1965 (NSW); Near corner of Llandillo Rd \& Blacktown Rd, Hind 5214 (NSW); The Glen, McBarron 631 (NSW); Veterinary Research Station, McBarron 8556 (NSW). Queensland. Stanthorpe, Bailey s.n. Dec 1875 (BRI); Tarong State Forest, Bean 13183 (NSW; EF173038*, EF173104*, EF173074*); Mt Moffatt N.P., NW of Injune, Bean 14273 (NSW; HQ184901, —, HQ184911); Lawnton, Blake 3055 (BRI); Samford near Brisbane, Blake 14939 (BRI); 82 km E of Cunnamulla on St George Rd, Dowling WP119 (BRI); Thulimbah, Stanthorpe Shire, Flesser s.n. 16 Jan 1997 (BRI); Western base of Mt Gillies, Forster 12115 (BRI); Blackdown Tableland, ca 35km SE of Blackwater, Henderson H1063 (BRI); Stanthorpe, Loryman s.n. 1911 (K); Beehive Dam, ca 4km NE of Wallangarra, Sharpe 1958 (BRI); Oxley Creek, Oxley Army Training Reserve, 25km ESE of Ipswich, Sharpe 5280 (BRI); 30 miles W of Pentland Township, Speck 4602 (BRI, K).

Nymphoides montana Aston - New South Wales. Maclaughlin River, at crossing of the Bombala to Cooma road, $6 \mathrm{~km}$ S of Nimmatabel, Aston 1820 (NSW); Braidwood to Nerriga road, Jerricknorra Creek at road crossing about $9 \mathrm{~km}$ by road, E of Charleyong, 
Aston 1822 (NSW); Braidwood to Nerriga road, Black Bobs Creek, about $2.6 \mathrm{~km}$ by road SW of the Corang River, equals about $13 \mathrm{~km}$ direct line SSW of Nerriga, Aston 1823 (NSW; HQ184902, —, HQ184912); Cooney Creek, $18 \mathrm{~km}$ by road E of Armidale on the Dorrigo Road, Aston 1837 (NSW); Bergen opposite Zoom Creek, at crossing of the Walcha to Uralla road, $5 \mathrm{~km} \mathrm{~N}$ of Walcha, Aston 1849 (NSW); ibid. Aston 1850 (NSW); Billi Bung Lagoon, 17 km N of Guyra, Bell 108 (NSW); Big Badja River, 5 miles N of Countegany, Briggs s.n. 28 Dec 1965 (NSW); Joorilands, Wollondilly River, 8 miles south-east of Yerranderie, Constable 5642 (NSW); Umeralla R., near Numeralla, Corbin s.n. Dec 1949 (NSW); Weddenjerry Lake, c. 14 km S of Bombala, Cann R. Hwy., Jacobs 6817 (NSW); Cecil Hopkins Reserve, Moss Vale Rd, Bowral, Jacobs 9950 (NSW; HQ184904, —, HQ184914); Paddys River, Hume Hwy, Jacobs 9951 (NSW; HQ184905, —, HQ184915); Bindook Swamp, 7 miles SW of Yerranderie, Johnson 1074 (NSW); SW end of Wingecarribee Swamp, c. $6.5 \mathrm{~km}$ due WNW of Robertson, $2.5 \mathrm{~km}$ due NNW of Burrawang, Kodela 208 (NSW; HQ184903, —, HQ184913); Black Bob's Creek, Moody 477 (CONN; EF173043, EF173108, EF173078). Victoria. Morass Creek, about 5 km N of Benambra, Aston 1853 (NSW). Cultivated. Lake Nadungamba, Mt. Annan Botanic Gardens, Jacobs 9376 (NSW; EF173045*, EF173109^, EF173080^); Hunter Valley, Jacobs 9948 (NSW; HQ184907, —, HQ184917); Probable origin Otways, Jacobs 9949 (NSW; HQ184906, —, HQ184916); Collected in Victoria, Pagels s.n. (CONN; EF173044, —, EF173079).

Nymphoides spinulosperma Aston - New South Wales. c. $13 \mathrm{~km}$ NNW of Collie, Aston 2878 (NSW; HQ184908, —, HQ184918); Oxley Highway, between Gilgandra and Warren, 14-15 km E of Collie, and $0.5 \mathrm{~km}$ E of the Berida-Innisfail road junction, Aston 2880 (NSW; FJ391928, —, HQ184919). Queensland. c. $96 \mathrm{~km} \mathrm{~S} \mathrm{of} \mathrm{Surat} \mathrm{on} \mathrm{the}$ St George road, Les 616 \& Jacobs 8605 (NSW; FJ391926*, FJ391941*, FJ391934*); St George, Wedd s.n. May 1894 (BRI). Victoria. c. $16 \mathrm{~km}$ by road (14 km in a straight line) W of St Arnaud along the Wimmera Highway, Aston 2869 (NSW; HQ184909, —, HQ184920). Cultivated. Hunter Valley, Jacobs 9947 (NSW; HQ184910, —, HQ184921); Collected in Victoria, Pagels s.n. (CONN; FJ391927, FJ391942, FJ391935).

Ingroup: Nymphoides aurantiaca (Dalzell) Kuntze (FJ391922, FJ391937, FJ391930); N. cambodiana (Hance) Tippery (FJ391929, FJ391943, FJ391936); N. cordata (Elliott) Fernald (EF173028, EF173096, EF173064); N. crenata (F.Muell.) Kuntze (EF173032, EF173099, EF173068); N. cristata (Roxb.) Kuntze (EF173033, EF173100, EF173069); N. exiliflora (F.Muell.) Kuntze (EF173036, EF173102, EF173072); N. indica (L.) Kuntze (EF173040, EF173106, EF173076); N. minima (F.Muell.) Kuntze (FJ391925, FJ391940, FJ391933); N. peltata (S.G.Gmel.) Kuntze (EF173046, EF173110, EF173081); N. thunbergiana (Griseb.) Kuntze (EF173048, EF173111, EF173082).

Outgroup: Liparophyllum capitatum (Nees ex Lehm.) Tippery \& Les (EF173053, EF173114, EF173086); L. congestiflorum (F.Muell.) Tippery \& Les (EU257161, EU257188, EU257174); L. exaltatum (Sol. ex Sims) Tippery \& Les (EF173054, EF173115, EF173087); L. exiguum (F.Muell.) Tippery \& Les (EF173035, EF173101, EF173071); L. gunnii Hook.f. (EF173024, EF173092, EF173061); L. lasiospermum (F.Muell.) Tippery \& Les (EF173056, EF173117, EF173089); L. latifolium (Benth.) Tippery \& Les (EU257163, EU257190, EU257176). 